\title{
Is prolactin a gonadotrophic hormone in red deer (Cervus elaphus)? Pattern of expression of the prolactin receptor gene in the testis and epididymis
}

\author{
H N Jabbour, L A Clarke, A S McNeilly, M Edery ${ }^{1}$ and \\ P A Kelly ${ }^{1}$
}

MRC Reproductive Biology Unit, 37 Chalmers Street, Edinburgh EH3 9EW, UK

${ }^{1}$ INSERM Unité 344, Faculté de Médecine Necker-Enfants Malades, Paris Cedex 15, France

(Requests for offprints should be addressed to H N Jabbour, MRC Reproductive Biology Unit, 37 Chalmers Street, Edinburgh EH3 9EW, UK)

\begin{abstract}
This study investigated the pattern and site of expression of the prolactin receptor gene in the testis and epididymis of red deer collected during the breeding season $(n=3)$. Ribonuclease protection assays using $50 \mu \mathrm{g}$ total RNA and a $300 \mathrm{bp}$ $\left[{ }^{32} \mathrm{P}\right]$-labelled antisense cRNA probe, generated from the extracellular domain of the red deer prolactin receptor, confirmed the expression of the receptor in both the testis and epididymis; a higher level of prolactin receptor mRNA was detected in the epididymis compared with the testis $\left(170 \cdot 4 \pm 1.5 \times 10^{3}\right.$ and $26 \cdot 3 \pm 2.7 \times 10^{3}$ arbitrary units respectively; $P<0 \cdot 05)$. In situ hybridisation using $300 \mathrm{bp}\left[{ }^{33} \mathrm{P}\right]$-labelled sense and antisense cRNA probes generated from the extracellular domain of the receptor localised the expression sites to the seminiferous tubules and interstitial compartments of the testis and the epithelial layer of the epididymal duct. Quantification of grain numbers demonstrated a higher level of expression of the
\end{abstract}

receptor in the epididymis compared with the interstitial and seminiferous tubule compartments of the testis $\left(18 \cdot 1 \pm 4 \cdot 4 \times 10^{2}, 10 \cdot 1 \pm 2 \cdot 0 \times 10^{2}\right.$ and $8 \cdot 3 \pm 0 \cdot 8 \times 10^{2}$ grains $/ \mu^{2}$ respectively; $P<0 \cdot 05$ ). However, no differences were detected in the level of expression of the receptor between the interstitial and seminiferous tubule compartments of the testis. Immunocytochemistry using an anti-prolactin receptor antibody, raised against a peptide sequence from the extracellular domain of the rat prolactin receptor, localised expression of the receptor gene to the Leydig cells, pachytene spermatocytes, round spermatids and elongating spermatids. In the epididymis, the receptor was localised to the epithelial layer within the epididymal ducts. Expression of the prolactin receptor gene in the red deer testis and epididymis suggests a role for the hormone in steroidogenesis and spermatogenesis. Fournal of Molecular Endocrinology (1998) 20, 175-182

\section{INTRODUCTION}

The red deer stag is a seasonal breeder that exhibits a circannual rhythm in reproductive activity that is inversely related to the prevailing plasma concentration of prolactin. Decreasing daylength of short days is accompanied by increased release of pituitary gonadotrophins and marked testicular recrudescence, leading to enhanced testosterone production, spermatogenesis and pronounced testicular growth (Lincoln 1971, Hochereau de Reviers \& Lincoln 1978, Barrell et al. 1985). In contrast, as daylength becomes progressively longer, there is a decrease in gonadotrophin and testosterone secretion and sperm production (Lincoln \& Kay 1979). The secretion of prolactin from the anterior pituitary also undergoes seasonal variation in the red deer stag: long photoperiods are marked by high circulating prolactin concentrations, while low prolactin concentrations characterise short photoperiods (Curlewis 1992).

The two basic functions of the testis, spermatogenesis and steroidogenesis, are controlled by follicle-stimulating hormone and luteinising hormone $(\mathrm{LH})$ respectively (Amann \& Schanbacher 1983). However, recently, there has been a growing interest in the positive effect that prolactin may have on testicular function. In rams, a positive 
correlation has been described between prolactin and testicular growth, testosterone production and LH receptor expression (Regisford \& Katz 1993, 1994). In addition, Lincoln et al. (1996) have demonstrated a low-amplitude cycle in testicular diameter in hypothalamo-pituitary disconnected (HPD) Soay sheep. In HPD rams, the testicular cycle persists despite the absence of gonadotrophin secretion in these rams and is positively correlated with prolactin concentration. These data strongly support the notion that prolactin acts directly at the testicular level and acts synergistically with gonadotrophins to regulate longterm cycles in testicular activity in seasonally breeding mammals such as the red deer and sheep. The increase in prolactin concentrations during long photoperiods is believed to be essential for priming the testis for redevelopment during the short-day period, at which time there is increased secretion of gonadotrophins (Sanford \& Dickson 1980, Howles et al. 1982, Sanford et al. $1984 a, b)$.

We have previously reported the cloning and sequencing of the prolactin receptor $\mathrm{cDNA}$ in red deer, which is predicted to encode a protein of 557 amino acids. The sequence in red deer differs from the long form of most other species by a $3^{\prime}$ truncation of the cytoplasmic domain. Despite this deletion, the receptor retains its functionality as assessed by tyrosine phosphorylation of the receptor, the associated protein Jak2 and the induction of transcription of the prolactin-responsive $\beta$-casein promoter (Jabbour et al. 1996). In northern hybridisation studies, prolactin receptor expression was evident in the testis of red deer stags during both the breeding and non-breeding seasons (Clarke et al. 1995). In addition, previous studies have confirmed that, in the testis, two forms are expressed that are encoded by transcripts of approximately $3 \cdot 5$ and $1.7 \mathrm{~kb}$ (Clarke et al. 1995, Jabbour et al. 1996). In the present study, we investigated whether, in red deer, prolactin exerts a direct effect on reproductive function through interaction with its membrane-bound receptors in the testis and epididymis. To this end, expression of the prolactin receptor gene was ascertained in the red deer testis and epididymis during the breeding season using the ribonuclease protection assay (RPA) technique. In addition, the site of expression of the receptors in both tissues was localised by in situ hybridisation using sense and antisense cRNA probes generated from the extracellular domain of the receptor. Finally, the prolactin-receptor-expressing cells in the testis and epididymis were identified by immunocytochemistry using an antiprolactin receptor antibody.

\section{MATERIALS AND METHODS}

\section{Animal and tissues}

Testis and epididymis were collected from three mature and sexually active red deer stags in September/October; this coincides with the period of transition from the non-breeding to the breeding season in this species in the United Kingdom. The testis and epididymis were removed shortly after the animals were killed. Samples utilised for RNA extraction were immediately snap frozen in liquid nitrogen and stored at $-70{ }^{\circ} \mathrm{C}$ until required for analysis. Tissues used for in situ hybridisation were mounted in tissuetek, snap frozen in isopentane in liquid nitrogen and stored at $-70{ }^{\circ} \mathrm{C}$ until required for further use. Samples utilised for immunocytochemistry were fixed in Bouin's solution for $5 \mathrm{~h}$ and stored in $70 \%$ ethanol overnight before processing for embedding in paraffin wax.

\section{Preparation of the prolactin receptor cDNA construct}

For preparation of the prolactin receptor riboprobes, a $300 \mathrm{bp}$ fragment (between bases -105 and 195 from the start codon) from the cervine prolactin receptor sequence was amplified by PCR using a clone encoding the full prolactin receptor cDNA (Jabbour et al. 1996) and the following primers: forward 5'-GCTAAAGAACGCTTCTGTTG-3' and reverse 5'-GTGGTAAGTCAGCGTG-3'. The amplified PCR product was subcloned into the pGEM vector and its identity confirmed by sequencing using the dideoxy nucleotide chaintermination method (Sanger et al. 1977). This construct was used for generation of riboprobe transcripts used in the RPA and in situ hybridisation studies.

\section{RNA extraction and ribonuclease protection assay}

RNA was extracted from the testis and epididymis using the guanidinium thiocyanate method (Chomczynski \& Sacchi 1987) and RNA yields were estimated by spectrophotometry at $260 \mathrm{~nm}$. In addition, liver RNA was prepared using the same procedure and utilised in the RPA as a positive control. Liver tissue has been shown previously to express the prolactin receptor gene abundantly in red deer at this stage of the breeding season (Clarke et al. 1995).

For the RPA, an antisense cRNA was prepared from plasmid containing a $300 \mathrm{bp}$ prolactin receptor cDNA (described above) after linearisation with SacI. The RPA was conducted using the Ambion RPA II kit (AMS Biotechnology Europe, Witney, 
Oxon, UK) as instructed by the manufacturer. Briefly, the linearised plasmid was incubated with T7 RNA polymerase in the presence of $\left[{ }^{32} \mathrm{P}\right]$ UTP $(800 \mathrm{Ci} / \mathrm{mmol}$, Amersham International plc, Amersham, Bucks, UK) mixed with loading dye (95\% formamide, $0.025 \%$ bromophenol blue, $0.025 \%$ xylene cyanol, $30 \%$ glycerol, $0 \cdot 5 \mathrm{mM}$ EDTA, $0 \cdot 025 \%$ SDS) heated at $95{ }^{\circ} \mathrm{C}$ for $3 \mathrm{~min}$ and separated on a denaturing $5 \%(\mathrm{w} / \mathrm{v})$ acrylamide gel for $3 \mathrm{~h}$ at $50 \mathrm{~W}$. The gel was then covered in Saran wrap and exposed for 2 min to XAR-5 film (Kodak, IBI, Cambridge, UK) to determine the location of the full-length radiolabelled cRNA. The appropriate portion of the gel was cut out, placed in an Eppendorf tube together with $350 \mu$ l elution buffer (containing $0.5 \mathrm{M}$ ammonium acetate, $1 \mathrm{mM}$ EDTA and $0 \cdot 2 \% \mathrm{w} / \mathrm{v}$ SDS) and incubated overnight at $37^{\circ} \mathrm{C}$. The activity of $2 \times 1 \mu \mathrm{l}$ aliquots was determined by liquid scintillation spectroscopy. The average of the samples was determined and the volume of radiolabelled probe required to give $2 \times 10^{5}$ c.p.m. calculated. Total RNA $(50 \mu \mathrm{g})$ from testis $(n=3)$ epididymis $(n=3)$, liver ( $n=1$; used as a positive control) and yeast $(n=2$; used as reaction controls in the presence or absence of RNase digestion to establish the specificity of the hybridisation reaction and the size of the unprotected RNA fragment) was mixed with the radiolabelled probe and hybridisation buffer, heated to $90{ }^{\circ} \mathrm{C}$ for $4 \mathrm{~min}$ and incubated overnight at $45^{\circ} \mathrm{C}$. The next day, single-stranded RNAs were digested using 250 units $/ \mathrm{ml} \mathrm{RNase} \mathrm{A} \mathrm{and} 10000$ units $/ \mathrm{ml}$ RNase $\mathrm{T} 1$ at $37^{\circ} \mathrm{C}$ for $30 \mathrm{~min}$. The protected RNA was precipitated and resuspended in gel loading buffer $(95 \%$ formamide, $0.025 \%$ xylene cyanol, $0.025 \%$ bromophenol blue, $0.5 \mathrm{mM}$ EDTA and $0.025 \% \mathrm{SDS}$ ), heated at $95{ }^{\circ} \mathrm{C}$ for $3 \mathrm{~min}$ and separated on a $5 \%$ acrylamide gel under denaturing conditions. The experiment was repeated twice and the gels were dried under vacuum and initially exposed to a phosphorescent screen (Molecular Dynamic, Chesham, Bucks, UK) followed by an autoradiographic film (XAR-5, Kodak).

Integrity of RNA and the relative amount of total RNA in each reaction was determined by including radiolabelled cRNA prepared from an $18 \mathrm{~S}$ ribosomal standard cDNA in each reaction. The amounts of prolactin receptor RNA and $18 \mathrm{~S}$ ribosomal RNA were counted on a phosphoimager (Molecular Dynamics). Differences between the amounts of prolactin receptor mRNA in the testis and epididymis were evaluated using analysis of variance.

\section{In situ hybridisation}

Cryostat tissue sections ( $5 \mu \mathrm{m}$ thick) were thawmounted onto 3-aminopropyltriethoxy silane
(TESPA)-coated and baked slides (2\% TESPA in acetone; Sigma Chemical Co., Poole, Dorset, UK) and fixed for $5 \mathrm{~min}$ in $4 \%$ (wt/vol) paraformaldehyde made up in $0 \cdot 1 \mathrm{M} \mathrm{PBS}$. The slides were acetylated and prehybridised for $2 \mathrm{~h}$ at $55{ }^{\circ} \mathrm{C}$ in prehybridisation buffer consisting of $50 \%$ deionised formamide, $5 \times \operatorname{SSPE}(1 \times \mathrm{SSPE}$ contains $0.15 \mathrm{M} \mathrm{NaCl}, 10 \mathrm{mM}$ $\mathrm{NaH}_{2} \mathrm{PO}_{4} \cdot \mathrm{H}_{2} \mathrm{O}$ and $1 \mathrm{mM}$ EDTA), $5 \times$ Denhardt's solution, $200 \mu \mathrm{g} / \mathrm{ml}$ yeast transfer RNA, $200 \mu \mathrm{g} / \mathrm{ml}$ denatured salmon sperm DNA and 1\% SDS. Hybridisation was then performed overnight in hybridisation buffer (prehybridisation buffer plus $4 \%$ dextran sulphate and $10 \mathrm{mM}$ dithiothreitol) containing $1 \times 10^{6}$ c.p.m. ${ }^{33}$ P-labelled cRNA. Excess probe was removed by washing in $4 \times \mathrm{SSC}$ $(1 \times \mathrm{SSC}$ contains $0.15 \mathrm{M} \mathrm{NaCl}, 15 \mathrm{mM}$ sodium citrate, $\mathrm{pH}$ 7) at room temperature before the sections were treated with ribonuclease A $(20 \mu \mathrm{g} /$ $\mathrm{ml})$. The sections were subsequently incubated with $4 \times \mathrm{SSC}, 2 \times \mathrm{SSC}$ and $0 \cdot 1 \times \mathrm{SSC}$ for $30 \mathrm{~min}$ each at room temperature. Tissues were dehydrated progressively in alcohols $(50 \%, 85 \%$ and $95 \%)$ containing $0.3 \mathrm{M}$ ammonium acetate and air-dried before they were dipped in NTB 2 emulsion (Kodak). After incubation in a humidified box overnight, tissues were placed in a sealed dark box at $4{ }^{\circ} \mathrm{C}$ for 3 weeks, developed with D19 developer, and fixed with Unifix (Kodak) at $14{ }^{\circ} \mathrm{C}$ in the dark-room.

Labelled sense and antisense cRNA were synthesised by incubation of linearised template $(1 \mu \mathrm{g})$ with $50 \mu \mathrm{Ci}\left[{ }^{33} \mathrm{P}\right] \mathrm{UTP}(2000 \mathrm{Ci} / \mathrm{mmol}$; Amersham) in the presence of T7 or SP6 RNA polymerase for $30 \mathrm{~min}$ at $37^{\circ} \mathrm{C}$ according to the manufacturer's recommendations (Promega, Southampton, UK).

Population density of grains in sections of testis and epididymis utilised in the in situ hybridisation studies were estimated using an Image Pro image analysis software linked to an Olympus BH2 microscope fitted with a dark-field condenser. The population density of grains determined for each section was the mean of grain density determined in a total of 25 fields of view that were selected in a systematic manner from a random start; this was established for the sense and antisense treatments in the testis and epididymis. The data were analysed by analysis of variance and pairwise comparisons were conducted using Fisher's protected LSD.

\section{Histology and immunocytochemistry}

Sections $5 \mu \mathrm{m}$ thick were cut and mounted on slides coated with $2 \%$ TESPA in acetone. Slides were then dried overnight at $50{ }^{\circ} \mathrm{C}$ before dewaxing in histoclear. Tissues were rehydrated in graded ethanol and washed in water followed by 
Tris-buffered saline (TBS: 0.05 M Tris- $\mathrm{HCl} \mathrm{pH}$ $7 \cdot 4,0 \cdot 85 \% \mathrm{NaCl}$ ). Sections were treated with $10 \%$ hydrogen peroxide in methanol for $30 \mathrm{~min}$ and then blocked for $30 \mathrm{~min}$ with normal swine serum (NSS) diluted $1: 5$ in TBS $+5 \%$ BSA. The primary antibody for the prolactin receptor (kindly donated by Dr P M Ingleton, School of Medicine, University of Sheffield) was raised against a 16 amino acid synthetic peptide corresponding to residues 53-68 of the external domain of the rat prolactin receptor (Nevalainen et al. 1996). This region shares an $87 \cdot 5 \%$ homology with the red deer prolactin receptor amino acid sequence. The polyclonal antibody was diluted in NSS-TBS $+5 \%$ BSA (see above) and incubated on the sections overnight at $4{ }^{\circ} \mathrm{C}$ under plastic coverslips. Control sections were incubated with non-immune rabbit serum. After removal of coverslips, sections were washed twice in TBS ( $5 \mathrm{~min}$ each), incubated for 30 min with biotinylated swine anti-rabbit immunoglobulin (Dako, High Wycombe, Bucks, UK) diluted $1: 500$ in NSS-TBS, then washed again twice in TBS (5 min each) and incubated with peroxidase antiperoxidase conjugated to avidinbiotin complex (Dako) for $30 \mathrm{~min}$ at room temperature. Colour reaction was developed by incubation in a mixture of $0.05 \% \quad 3,3^{\prime}$-diaminobenzidine (Sigma) in $10 \mathrm{ml} \mathrm{0.05} \mathrm{M} \mathrm{Tris-HCl} \mathrm{buffer} \mathrm{(pH} \mathrm{7.4)}$ and $0.033 \%$ hydrogen peroxide.

\section{RESULTS}

The results from a typical ribonuclease protection assay are shown in Fig. 1. The ribonuclease protection assays confirmed the expression of the prolactin receptor gene in both the testis and the epididymis of the red deer at the begining of the breeding season (Fig. 1); no protected bands were observed in the yeast RNA sample after RNase digestion. Whereas all samples contained comparable levels of $18 \mathrm{~S}$ ribosomal RNA, the amount of prolactin receptor RNA was significantly greater in the epididymis than in the testis: the arbitrary counts assigned $(n=3)$ using a phosphoimager were $170 \cdot 4 \pm 1.5 \times 10^{3}$ and $26 \cdot 3 \pm 2.7 \times 10^{3}$ respectively $(P<0 \cdot 05$; mean \pm s.E.M. $)$.

The results from a typical in situ hybridisation of the testis and epididymis are presented in Fig. 2; this pattern of expression was detected in each animal. The sections confirm the expression of the receptor gene both in the Leydig cells and within the seminiferous tubule compartment of the testis. In addition, in the epididymis the expression was localised to the epithelial layer of the epididymal duct. In order to compare the level of expression of the receptor gene in the epididymis and the testis,

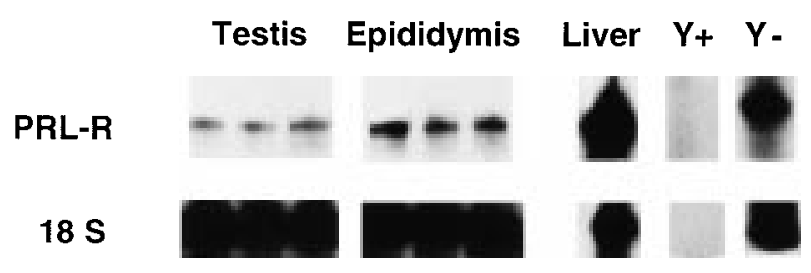

FIGURE 1. RPA conducted using $50 \mu \mathrm{g}$ total RNA isolated from testis and epididymis of red deer and a $300 \mathrm{bp}$ homologous prolactin receptor cRNA probe generated from the extracellular domain. Liver RNA $(50 \mu \mathrm{g})$ was included as a positive control and yeast RNA with (+) and without (-) RNase digestion were used as reaction controls. Integrity of RNA and the relative amount of total RNA in each reaction was determined using a ribosomal $18 \mathrm{~S}$ cRNA probe.

grain counts were performed on all sections. The population density counts of grains (mean \pm s.E.M.) are illustrated in Fig. 3; the grain counts in the sections exposed to the sense probe were negligible and comparable across all sections. Hybridisation with the antisense probe demonstrated a comparable level of expression of the receptor gene between the Leydig cells and the seminiferous tubule compartment of the testis $\left(10.1 \pm 2.0 \times 10^{2}\right.$ and $8 \cdot 3 \pm 0 \cdot 8 \times 10^{2}$ grains $/ \mu \mathrm{m}^{2}$ respectively; $n=3$ ), but expression of the receptor gene in the epididymis $\left(18 \cdot 1 \pm 4 \cdot 4 \times 10^{2}\right.$ grains $\left./ \mu^{2} ; n=3\right)$ was significantly greater $(P<0.05)$ than that observed in either compartment of the testis.

Immunochemistry using an antibody that was directed against a conserved peptide sequence derived from the extracellular domain of the rat prolactin receptor localised further the site of expression of the receptor gene in the red deer testis and epididymis (Fig. 4). In the testis, expression was localised to the Leydig cells within the interstitial region. In addition, in the seminiferous tubules localised expression of the receptor was detected in pachytene spermatocytes, round spermatids and elongating spermatids. There was no notable expression localised in mature spermatozoa. In the epididymis, immunohistochemistry localised the site of expression of the receptor gene to the epithelial cell layer.

\section{DISCUSSION}

The data presented here confirm the expression of the prolactin receptor gene in the testis and epididymis of red deer. This suggests that, in red deer, the pituitary hormone, prolactin, may be involved in testicular function. Localisation of expression of the receptor gene in the seminiferous tubule (germ cells) and interstitial (Leydig cells) 

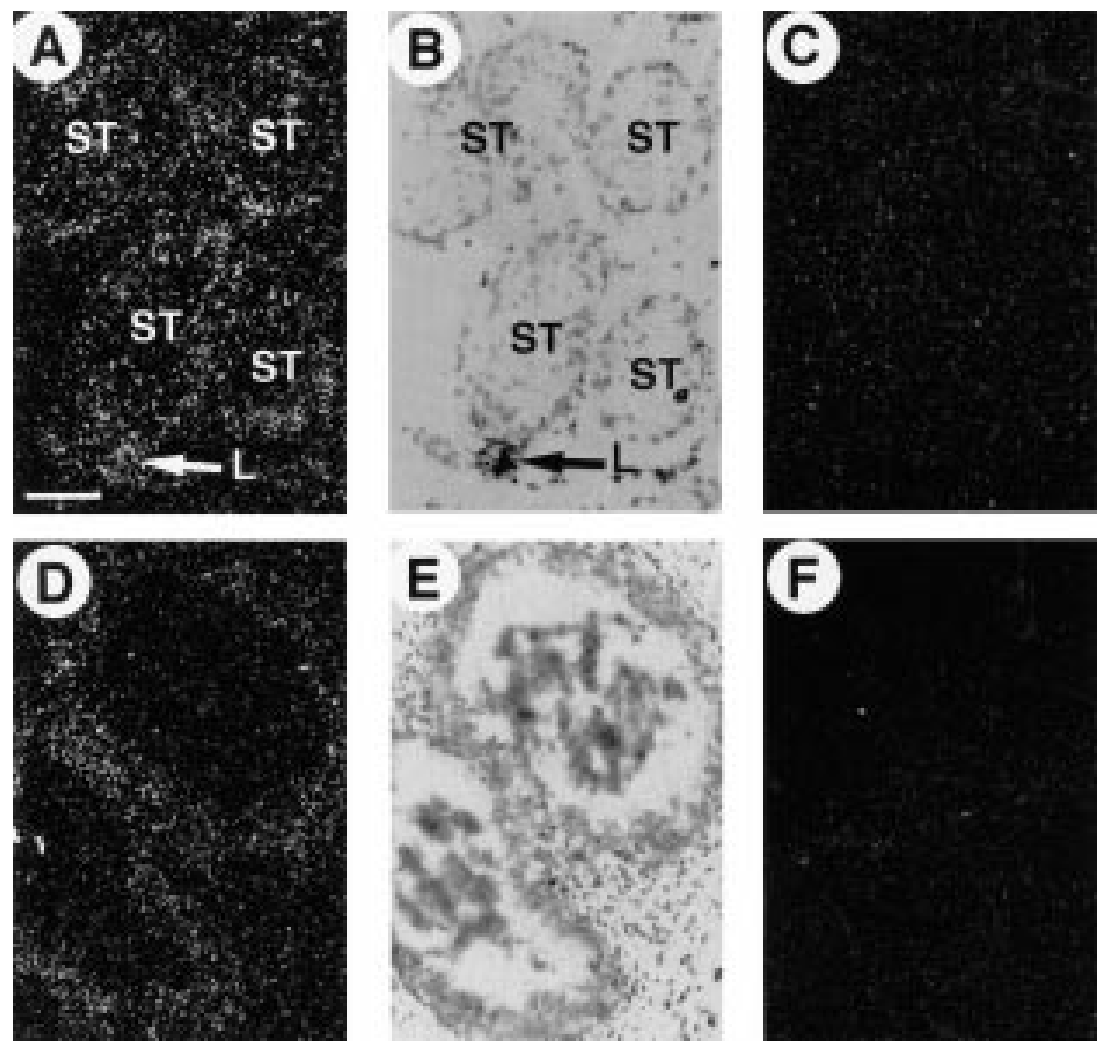

FIGURE 2. In situ hybridisation of prolactin receptor in the testis and epididymis of red deer. Prolactin receptor expression was localised in Leydig cells (L), and the seminiferous tubular (ST) compartment of the testis (A, B: dark- and light-field images after hybridisation with the antisense probe; $\mathrm{C}$ : dark-field image after hybridisation with the sense probe) and in the epithelial layer within the epididymis $(\mathrm{D}, \mathrm{E}$ : dark- and light-field images after hybridisation with the antisense probe; $\mathrm{F}$ : dark-field image after hybridisation with the sense probe). Bar represents $100 \mu \mathrm{m}$.

compartments implicates prolactin as a possible gonadotrophic hormone regulating the processes of both spermatogenesis and steroidogenesis in ungulate species. In addition, the expression of prolactin receptors in the epididymis of red deer suggests a more generalised function for the hormone in male reproductive physiology.

Expression of the prolactin receptor gene in the Leydig cells is consistent with the well-described role of prolactin in steroidogenesis. Normal physiological prolactin concentrations have been shown to be important for maintenance of testosterone secretion during the breeding season in sheep (Yarney \& Sanford 1989). Also in sheep, treatment with bromocriptine during the autumn months to suppress prolactin secretion results in reduced testosterone secretion (Regisford \& Katz 1993). Evidence in rodent species suggests that prolactin influences testosterone secretion through the stimulation and maintenance of expression of LH receptors in Leydig cells (Klemcke et al. 1984, Takase et al. 1990) or by regulating specific enzymatic steps in androgen biosynthesis (Chandrashekar \& Bartke 1988).

Expression of prolactin receptors within the seminiferous tubules suggests that prolactin may be involved directly in the process of spermatogenesis. There are considerable data supporting a positive relationship between prolactin secretion and testicular physiology in ungulate species. In intact rams, treatment with bromocriptine to suppress circulating prolactin concentrations during the sexually inactive period causes a decrease in testicular size (Sanford \& Dickson 1980, Regisford \& Katz 1993) and spermatozoa production (Sanford \& Dickson 1980), or a delay in testicular recrudescence. Circannual cycles in testicular activity were better expressed in rams maintained under long days, 


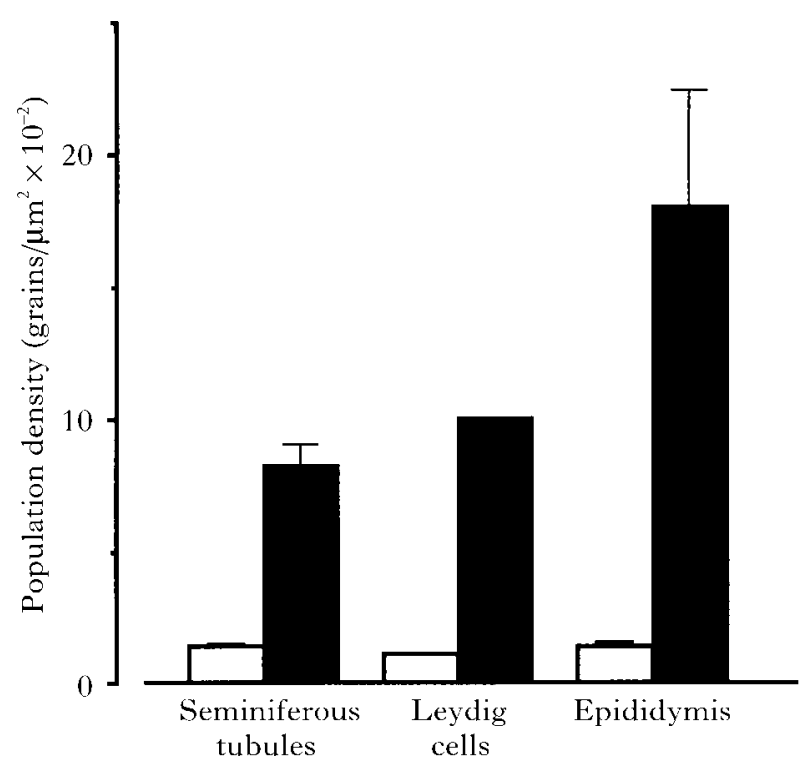

FIGURE 3. Population density of grains in sections of testis (the seminiferous tubule compartment and Leydig cells) and epididymis used in the in situ hybridisation studies for the prolactin receptor. Values are mean \pm S.E.M. of grain density determined in a total of 25 fields of view that were selected in a random and systematic manner. Open bars, sense probe; solid bars, antisense probe.

when circulating prolactin concentrations varied from high to low with a fixed temporal association with testicular volume, compared with rams living continuously under short days, when prolactin secretion was chronically suppressed (Howles et al. 1982).

Further evidence for a stimulatory role for prolactin in testicular activity has been established in HPD Soay rams. These rams express a persistent low-amplitude cycle in testicular diameter that is positively correlated with the long-term changes in prolactin secretion (Lincoln et al. 1996). Morphometric analysis of the testis of HPD rams demonstrated evidence of spermatogenesis, with the presence of pachytene/diplotene primary spermatocytes, which may be regulated by prolactin (Lincoln et al. 1996). These data suggest that, during the summer months, prolactin may be involved in the initiation of the process of spermatogenesis, and that it facilitates the rapid reactivation of testicular function in response to the increased secretion of gonadotrophins, and consequently androgens, in the autumn months of the breeding season. This hypothesis is supported by the detection of prolactin receptor gene expression during the breeding and non-breeding seasons of red deer (Clarke et al. 1995). Moreover, localisation of expression of the prolactin receptor gene in the seminiferous tubule compartment and in Leydig cells suggests a role for prolactin in the processes of spermatogenesis and steroidogenesis in the red deer testis. The pattern of expression of the prolactin receptor gene on germ cells may imply a role for prolactin in the differentiation of spermatocytes or the regulation of the cell division cycle, or both, by acting as a meiotic inducer. In concert with gonadotrophins, prolactin may be an important factor in enhancing the efficiency of spermatogenesis. This is supported further by observations that administration of prolactin to immature hypophysectomised rats increases the number of spermatocytes (Dombrowicz et al. 1992) that are known to express the receptor in vivo (Hondo et al. 1995).

Prolactin is not able to enter the adluminal compartment of the seminiferous epithelium because of the blood-tubule barrier. This raises the question of the mechanism of transport of prolactin across such a barrier. One possibility is that it occurs through the expression of prolactin transport proteins that would act as prolactin transmembrane carriers, to ensure transport of prolactin from the interstitial into the seminiferous tubule compartment. In red deer testis, two forms of the prolactin receptor have been identified which are encoded by transcripts of approximately 3.5 and $1.7 \mathrm{~kb}$. The $3.5 \mathrm{~kb}$ transcript is known to encode the long-form membrane-bound receptor (Jabbour et al. 1996), but the smaller transcript may encode a nonmembrane-bound receptor protein that would act as a prolactin transporter (Jabbour \& Kelly 1997). Future work will investigate the function of the shorter prolactin receptor transcript and the possible differential site of expression of the two prolactin receptor isoforms in the testis. This may provide further insight into the exact role of prolactin in spermatogenesis and its possible mode of transport into the seminiferous tubule compartment.

Prolactin receptor expression was also detected, by in situ hybridisation and immunocytochemistry, in the epithelial layer of the epididymal duct. The exact role of prolactin in the epididymis remains to be elucidated. However, prolactin is believed to maintain epididymal weight, stimulate testosterone uptake, promote fluid exchange across the epididymal epithelium (Brumlow \& Adams 1990) and stimulate the production of epididymal steroids that contribute to the steroid content of seminal plasma (Hamilton \& Fawcett 1970). It is also possible that prolactin is involved in promoting mitogenesis and regeneration of the epithelial layer of the epididymis. Lincoln (1971) has shown that the epididymal weight and the height of the epithelial layer undergo seasonal variation, with initiation of growth coinciding with the period of increased 

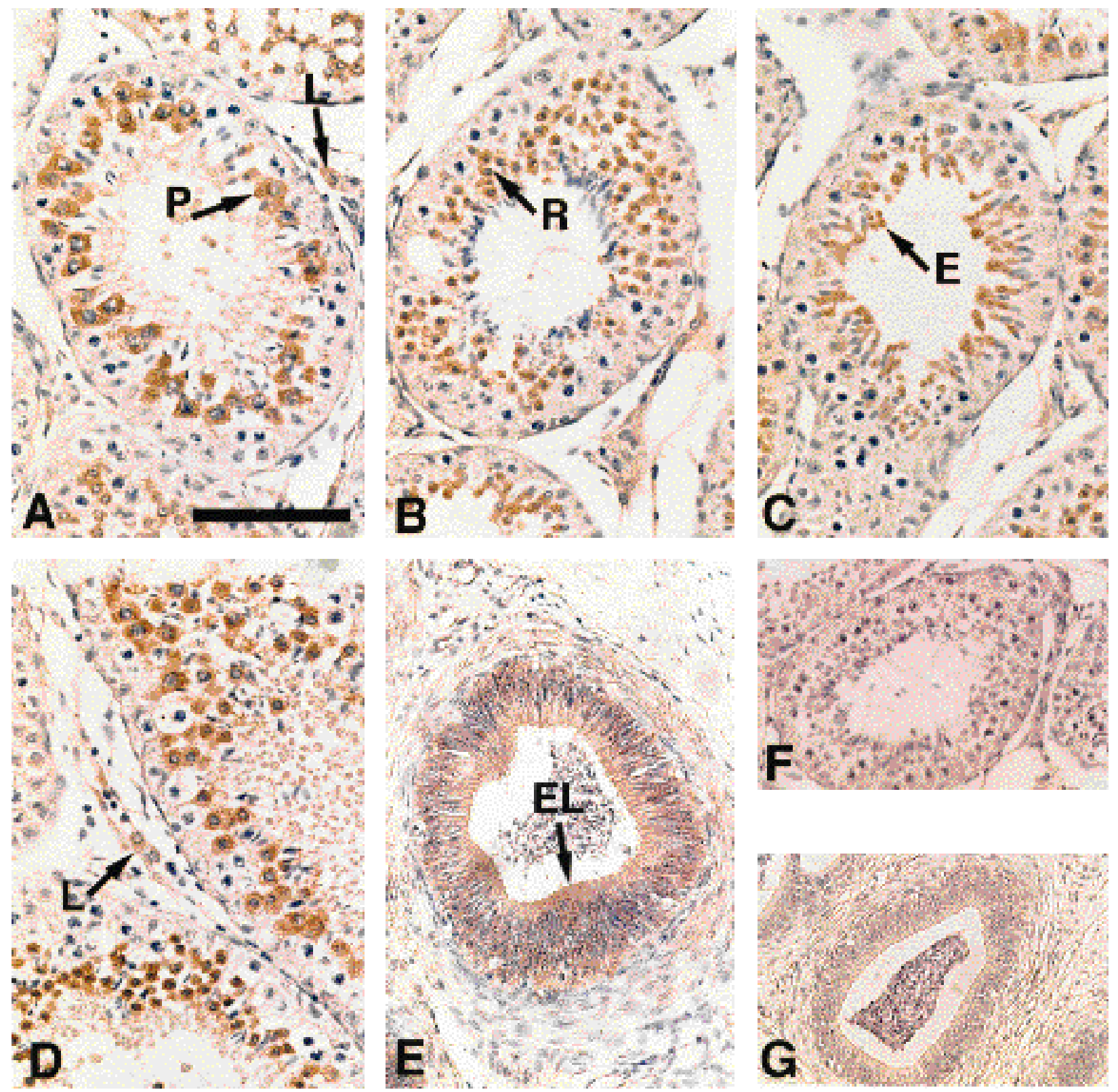

FIGURE 4. Immunocytochemical staining for prolactin receptor in the testis (A-D) and epididymis (E) of red deer. In the testis, expression of the receptor was localised in pachytene spermatocytes $(\mathrm{P})$, round $(\mathrm{R})$ and elongating $(\mathrm{E})$ spermatids and Leydig cells (L). In the epididymis, expression of the receptor was localised to the epithelial layer (EL). Negative controls for testis (F) and epididymis $(G)$ are shown. The sections were counterstained with haematoxylin. Bar represents $100 \mu \mathrm{m}$.

endogenous prolactin secretion. Prolactin has been demonstrated to promote cell division and mitogenesis after interaction with its membranebound receptors (Das \& Vonderhaar 1995). This function of prolactin is believed to be mediated through activation of the mitogen activated protein kinase pathway (Das \& Vonderhaar 1995).
In conclusion, this study has confirmed the expression of prolactin receptors in the red deer testis and epididymis. Localisation of the site of expression of the receptors to the seminiferous tubule and interstitial compartments of the testis suggests that prolactin may promote both the spermatogenic and the steroidogenic function of the 
testis, and thus act as a gonadotrophic hormone in seasonally breeding mammals such as red deer.

\section{ACKNOWLEDGEMENTS}

The authors would like to acknowledge Dr P M Ingleton for the supply of prolactin receptor antibody and Ms JoAnne McVerry and Ms Sheila Boddy for skilful technical assistance. We also wish to thank Mr Mike Millar for expert advice and assistance with the in situ hybridisation and the immnocytochemistry and Mr John Fletcher for the provision of testis and epididymal samples. This work was supported by a BBSRC project grant awarded to $\mathrm{H} \mathrm{N}$ Jabbour.

\section{REFERENCES}

Amann RP \& Schanbacher BD 1983 Physiology of male reproduction. Fournal of Animal Science 57 380-403.

Barrell GK, Muir PD \& Sykes AR 1985 Seasonal profiles of plasma testosterone, prolactin and growth hormone in red deer stags. In The Biology of Deer Production, pp 185-190. Eds P Fennessey \& K Drew. New Zealand: The Royal Society of New Zealand.

Brumlow WM \& Adams CS 1990 Immunocytochemical detection of prolactin or prolactin-like immunoreactivity in epididymis of mature male mouse. Histochemistry $\mathbf{9 3}$ 299-304.

Chandrashekar V \& Bartke A 1988 Influence of endogenous prolactin on luteinising hormone stimulation of testicular steroidogenesis and the role of prolactin in the adult male rat. Steroids 5 559-576.

Chomczynski P \& Sacchi N 1987 Single-step method of RNA isolation by acid guanidinium thiocyanate phenol-chloroform extraction. Analytical Biochemistry 162 156-159.

Clarke LA, Edery M, Loudon ASI, Randall VA, Postel-Vinay MC, Kelly PA \& Jabbour HN 1995 Expression of the prolactin receptor gene during the breeding and nonbreeding seasons in red deer (Cervus elaphus): evidence for the expression of two forms in the testis. Fournal of Endocrinology 146 313-321.

Curlewis LD 1992 Seasonal prolactin secretion and its role in seasonal reproduction: a review. Reproduction, Fertility and Development 4 1-23.

Das R \& Vonderhaar BK 1995 Translation of prolactin's (PRL) growth signal through both long and short forms of the PRL receptor. Molecular Endocrinology 9 1750-1759.

Dombrowicz D, Sente B, Closset J \& Hennen G 1992 Dosedependent effects of human prolactin on the immature hypophysectomised rat testis. Endocrinology 130 695-700.

Hamilton DW \& Fawcett DW 1970 In vitro synthesis of cholesterol and testosterone from acetate by rat epididymis and vas deferens. Proceedings of the Society for Experimental Biology and Medicine 133 693-695.

Hochereau de Reviers MT \& Lincoln GA 1978 Seasonal variation in the testicular histology of the red deer stag (Cervus elaphus). Fournal of Reproduction and Fertility $\mathbf{5 4}$ 209-213.

Hondo E, Kurohmaru M, Sakai S, Ogawa K \& Hayashi Y 1995 Prolactin receptor expression in rat spermatogenic cells. Biology of Reproduction 52 1284-1290.

Howles CM, Craigon J \& Haynes NB 1982 Long-term rhythms in testicular volume and plasma prolactin concentrations in rams reared for 3 years in constant photoperiod. Fournal of Reproduction and Fertility 65 439-446.

Jabbour HN \& Kelly PA 1997 Prolactin receptor subtypes: a possible mode of tissue specific regulation of prolactin function. Reviews of Reproduction 2 14-18.

Jabbour HN, Clarke LA, Boddy S, Pezet A, Edery M \& Kelly PA 1996 Cloning, sequencing and functional analysis of a truncated cDNA encoding red deer prolactin receptor: an alternative tyrosine residue mediates $\beta$-casein promoter activation. Molecular and Cellular Endocrinology 123 $17-26$.

Klemcke HG, Bartke A \& Borer KY 1984 Regulation of testicular prolactin and luteinising hormone receptors in golden hamsters. Endocrinology 114 594-603.

Lincoln GA 1971 The seasonal reproductive changes in the red deer stag (Cervus elaphus). Fournal of Zoology 163 $105-123$.

Lincoln GA \& Kay RNB 1979 Effect of season on the secretion of $\mathrm{LH}$ and testosterone in intact and castrated red deer stags (Cervus elaphus). Fournal of Reproduction and Fertility $\mathbf{5 5}$ $75-80$.

Lincoln GA, Clarke GA \& Sweeney T 1996 Hamster-like cycles in testicular size in the absence of gonadotrophin secretion in HPD rams exposed to long-term changes in photoperiod and treatment with melatonin. Fournal of Neuroendocrinology 8 855-866.

Nevalainen MT, Valve EM, Ingleton PM \& Härkönen PL 1996 Expression and hormone regulation of prolactin receptors in rat dorsal and lateral prostate. Endocrinology 137 3078-3088.

Regisford EGC \& Katz LS 1993 Effects of bromocriptineinduced hypoprolactinemia on gonadotrophin secretion and testicular function in rams (Ovis aries) during two seasons. Fournal of Reproduction and Fertility 99 529-537.

Regisford EGC \& Katz LS 1994 Testicular LH receptor numbers are dependent on serum prolactin (PRL) concentrations in the ram. Biology of Reproduction $\mathbf{5 0}$ (Supplement 1) 112.

Sanford LM \& Dickson KA 1980 Seasonality in reproductive processes in rams with suppressed prolactin secretion. Fertility and Sterility 34 192-193.

Sanford LM, Howland BE \& Palmer WM 1984a Seasonal changes in the endocrine responsiveness of the pituitary and testes of male sheep in relation to their patterns of gonadotrophic hormone and testosterone secretion. Canadian Fournal of Physiology and Pharmacology 62 827-833.

Sanford LM, Howland BE \& Palmer WM $1984 b$ Seasonal changes in the secretion of gonadotrophic hormones and in the endocrine response of the pituitary of male sheep in the absence of gonadal influence. Canadian Fournal of Physiology and Pharmacology 62 834-839.

Sanger F, Niklen S \& Coulson AR 1977 DNA sequencing with chain terminating inhibitors. Proceedings of the National Academy of Sciences of the USA 74 5463-5467.

Takase M, Tsutsui K \& Kawashima S 1990 Effects of prolactin and bromocriptine on the regulation of testicular luteinising hormone receptors in mice. Fournal of Experimental Zoology 256 200-209.

Yarney TA \& Sanford LM 1989 Pubertal changes in the secretion of gonadotropic hormones, testicular gonadotropic receptors and testicular function in the ram. Domestic Animal Endocrinology 6 219-229.

RECEIVED 15 July 1997

ACCEPTED 1 October 1997 